\title{
Multi-species larval fish growth model based on temperature and fluorometrically derived RNA/DNA ratios: results from a meta-analysis
}

\author{
L. J. Buckley ${ }^{1}$, E. M. Caldarone ${ }^{2, *}$, C. Clemmesen ${ }^{3}$ \\ ${ }^{1}$ University of Rhode Island/NOAA Cooperative Marine Education and Research Program, \\ Graduate School of Oceanography, South Ferry Road, Narragansett, Rhode Island 02882, USA \\ ${ }^{2}$ NOAA National Marine Fisheries Service, Narragansett Laboratory, 28 Tarzwell Drive, Narragansett, \\ Rhode Island 02882, USA \\ ${ }^{3}$ Leibniz Institute of Marine Sciences, IFM-GEOMAR, Düsternbrooker Weg 20, 24105 Kiel, Germany
}

\begin{abstract}
Weight-specific growth rate (G) and growth performance (the fraction of maximum growth realized, $\mathrm{G}_{\mathrm{pf}}$ ) are key demographic characteristics. The ratio of RNA/DNA (RD) can provide information on both $\mathrm{G}$ and $\mathrm{G}_{\mathrm{pf}}$. Estimating $\mathrm{G}$ from $\mathrm{RD}$ in larval fish requires an adjustment for the activity of RNA at different temperatures. Based on a meta-analysis of published data, we present a general model for the relationship between $\mathrm{G}$ in marine fish larvae and fluorometrically derived RD and temperature $(\mathrm{T})$, and suggest that this model can be used to estimate $\mathrm{G}$ in marine fish larvae. Several options for estimating $G_{p f}$ are also considered, including the use of a reference growth rate $\left(\mathrm{G}_{\mathrm{ref}}\right)$. RDs of well-fed larvae appeared to be independent of water temperatures between 4 and $28^{\circ} \mathrm{C}$, suggesting that any increase in growth rate with temperature was accomplished by increased activity rather than increased concentrations of RNA. However, for the best-fit meta-analysis RD-T-G model, the relationship between $\mathrm{RD}$ and $\mathrm{G}_{\mathrm{pf}}$ was temperature dependent for fish less than fully fed.
\end{abstract}

KEY WORDS: RNA/DNA ratio $\cdot$ Growth $\cdot$ Larvae $\cdot$ Temperature effects $\cdot$ Nucleic acids $\cdot$ Fluorometric microplate assay $\cdot$ Multi-species meta-analysis

Resale or republication not permitted without written consent of the publisher

\section{INTRODUCTION}

There are only a few widely used approaches to estimating the recent growth rate of an individual fieldcaught fish larva, among them being otolith daily increment width (Campana \& Neilson 1985, Campana 2001, Jones 2002) and nucleic acid analysis (the RNA/ DNA ratio, $\mathrm{RD})$. RD values have been shown to decrease after $1 \mathrm{~d}$ of food deprivation and correlate well with growth rates over periods up to about 1 wk (Clemmesen 1994, Buckley et al. 1999, Caldarone 2005). This short time frame opens up the possibility of linking environmental conditions at the time of sampling to variability in growth and survival.

Growth in larval fish is primarily accomplished through elaboration of muscle protein. While the amount of ribosomal RNA sets the capacity for protein synthesis, DNA remains relatively constant in a cell. Thus over the past 3 decades, RD has been widely used as an index of nutritional condition (Clemmesen 1994, Clemmesen et al. 1997, Grønkjær et al. 1997, Buckley et al. 1999, St. John et al. 2001) and, to a lesser extent, as a means to estimate weight-specific growth rate (G) in fish larvae (Buckley 1984, Caldarone et al. 2003, Caldarone 2005, Malzahn et al. 2007). Since the actual rate of translation (protein synthesis per unit RNA) varies with temperature (Millward et al. 1973, Preedy et al. 1988, Farewell \& Neidhardt 1998), estimating G from $\mathrm{RD}$ in ectotherms requires an adjustment for the activity of RNA due to temperature. Ideally, laboratory experiments conducted at different feeding levels and water temperatures are used to define the relationship 
Table 1. Published RD-T-G models. All models are of the form: $\mathrm{G}_{\%}=\mathrm{m}_{1} \times \mathrm{RD}+\mathrm{m}_{2} \times \mathrm{T}+\mathrm{C}_{1}$. $\mathrm{G}_{\%}=\mathrm{DNA}$ - or protein-specific growth rate in \%, RD $=$ RNA/DNA ratio (not standardized) of whole larval fish, $\mathrm{T}=$ rearing temperature in ${ }^{\circ} \mathrm{C}, \mathrm{m}_{1}$ and $\mathrm{m}_{2}$ are coefficients, and $\mathrm{C}_{1}$ is a constant. Method = nucleic acid analytical method; samples = individual larvae or pooled samples

\begin{tabular}{|c|c|c|c|c|c|c|c|c|c|c|}
\hline Species & $\begin{array}{l}\text { Rearing } \\
\text { temp. } \\
\text { range }\left({ }^{\circ} \mathrm{C}\right)\end{array}$ & $\mathrm{G}_{\%}$ & $\begin{array}{l}\mathrm{m}_{1} \\
\mathrm{RD}\end{array}$ & $\begin{array}{c}\mathrm{m}_{2} \\
\mathrm{~T}\end{array}$ & $\mathrm{C}_{1}$ & $r^{2}$ & $\mathrm{n}$ & Method & Samples & Source \\
\hline $\begin{array}{l}\text { Winter flounder Pseudo- } \\
\text { pleuronectes americanus }\end{array}$ & $5-10$ & Protein & 3.02 & 1.38 & -14.83 & 0.72 & 50 & UV absorption & Pooled & $\begin{array}{l}\text { Buckley } \\
\text { (1982) }\end{array}$ \\
\hline 8 temperate marine species & $2-20$ & Protein & 4.75 & 0.93 & -18.18 & 0.92 & 23 & UV absorption & Pooled & Buckley (1984) \\
\hline $\begin{array}{l}\text { Sand lance Ammodytes } \\
\text { americanus }\end{array}$ & $2-9$ & Protein & 4.24 & 0.49 & -13.52 & 0.61 & 57 & UV absorption & Pooled & $\begin{array}{c}\text { Buckley et al. } \\
(1984)\end{array}$ \\
\hline Herring Clupea harengus & $10-18$ & DNA & 3.05 & 0.68 & -9.92 & 0.70 & 28 & $\begin{array}{l}\text { Spectrofluoro- } \\
\text { metric microplate }\end{array}$ & Pooled & $\begin{array}{l}\text { Folkvord et al. } \\
\text { (1996) }\end{array}$ \\
\hline Atlantic cod Gadus morhua & $3-9$ & Protein & 4.03 & 0.88 & -11.16 & 0.37 & 128 & $\begin{array}{l}\text { Spectrofluoro- } \\
\text { metric microplate }\end{array}$ & Individual & $\begin{array}{l}\text { Caldarone et al. } \\
\qquad(2003)\end{array}$ \\
\hline $\begin{array}{l}\text { Haddock Melanogrammus } \\
\text { aeglefinus }\end{array}$ & $6-10$ & Protein & 4.61 & 1.18 & -17.31 & 0.52 & 102 & $\begin{array}{l}\text { Spectrofluoro- } \\
\text { metric microplate }\end{array}$ & Individual & $\begin{array}{l}\text { Caldarone } \\
\text { (2005) }\end{array}$ \\
\hline $\begin{array}{l}\text { Haddock and cod (combined } \\
\text { data set) }\end{array}$ & d $3-10$ & Protein & 4.67 & 0.96 & -15.3 & 0.45 & 172 & $\begin{array}{l}\text { Spectrofluoro- } \\
\text { metric microplate }\end{array}$ & Individual & $\begin{array}{l}\text { Caldarone } \\
\text { (2005) }\end{array}$ \\
\hline
\end{tabular}

among $\mathrm{RD}$, temperature $(\mathrm{T})$ and $\mathrm{G}(\mathrm{RD}-\mathrm{T}-\mathrm{G}$ relationship). These calibration experiments require specialized rearing facilities, are costly, and labor intensive. Consequently, only a few calibrations are available for a very limited number of species (Table 1), thus hampering the widespread use of RD for estimating $G$ in fish larvae.

A variety of analytical methods have been used to estimate RNA and DNA concentrations in fish larvae. Because RD values are sensitive to the choice of procedures used, any meta-analysis of RD values from different laboratories has been problematic. This issue was addressed in a recent international intercalibration effort (Caldarone et al. 2006) whereby fluorometrically derived $\mathrm{RD}$ estimates were standardized based on the slopes of the RNA and DNA standard curves (Berdalet et al. 2005). This standardization method opens up both the possibility of comparing fluorometrically derived RD among laboratories, and using RD-T-G relationships developed in other laboratories.

Buckley (1984), using an UV method for analysis of $\mathrm{RD}$, presented a RD-T-G calibration model based on data from larvae of 8 species of temperate marine fishes (Table 1), and suggested that there was a single relationship among RD-T-G that was independent of species. Although this general model has been used for several species, the conclusion that there is a single RD-T-G relationship in larvae of temperate marine fishes has not been further tested. Moreover, no general model based on the newer fluorometric methods has been published. To examine these and other issues, we propose the following hypotheses: (1) A single RD-T-G relationship can be used for all species of marine fish larvae, (2) RD of a well-fed larva does not change with water temperature, (3) G-values resulting from a RD-T-G relationship can be used to estimate growth performance (the fraction of maximum growth realized, $G_{p f}$ ), and (4) RD can be used as a direct index of condition without adjustment for the effect of water temperature on the activity of RNA. Underlying these hypotheses is a more fundamental question: How is the increase in $\mathrm{G}$ that sometimes accompanies an increase in temperature accomplished?

This paper addresses the above and related questions by analyzing RD data from relevant literature and by reanalyzing results from laboratory and field studies after standardizing the RD values for direct comparability. The effect of larval size and other variables on the estimation of $\mathrm{G}$ and $\mathrm{G}_{\mathrm{pf}}$ using bulk nucleic acid analysis is also considered.

\section{METHODS}

A combined data set was constructed using raw values of RD, T and G obtained from the literature. Only data which met all of the following conditions were included: (1) RD values were obtained from whole larval fish, (2) nucleic acid values were obtained from 1-dye spectrofluorometric assays, and (3) an average ratio of the slopes of the RNA and DNA standard curves was available from the researchers. All RD values were standardized (sRD) according to the procedure described in Caldarone et al. (2006) using 2.4 as the reference slope-ratio value. sRD values were used in all analyses. 
A subset of the combined data set was used to examine the sRD-T-G relationship. This data set (hereafter called growth model data set, Table 2) was limited to studies where instantaneous growth coefficients were available or could be calculated using the equation:

$$
\mathrm{G}=\left(\ln \mathrm{W}_{2}-\ln \mathrm{W}_{1}\right) /\left(\mathrm{t}_{2}-\mathrm{t}_{1}\right)
$$

where $\mathrm{W}_{2}$ and $\mathrm{W}_{1}$ are measures of larval size (length, dry weight, protein content) at time $t_{2}$ and $t_{1}$. When necessary, specific growth in \% $\mathrm{d}^{-1}\left(\mathrm{G}_{\%}\right)$ was converted to $G$ by dividing values by 100 , adding 1 , and taking the natural log. Coefficients based on dry weights or protein were used directly. A lengthweight relationship of $\mathrm{W}=0.0128\left(\mathrm{~L}_{\mathrm{cm}}\right)^{3}$ (where $\mathrm{L}_{\mathrm{cm}}=$ length in centimeters) (Kondo et al. 1976 cited by Suda \& Kishida 2003) was used to convert growth-in-length data to growth-in-weight for the 2 Japanese sardine studies, and a length exponent of 3.3 (Herzka \& Holt 2000) was used for the 2 red drum studies (Table 2). Growth intervals were restricted to those ranging from
2 to $7 \mathrm{~d}$. For each study, an average sRD and $\mathrm{G}$ for each combination of food level and temperature was calculated.

A second subset of the combined data set was used to examine sRD values of well-fed fish (hereafter called well-fed fish data set, Table 2). This data set was limited based on the following considerations: Laboratory reared larvae often exhibit an initial decrease in RD from hatching, followed by an increase through time to a plateau value, which is at or above the hatch value (Richard et al. 1991, Clemmesen 1994, Westerman \& Holt 1994, Caldarone 2005). For each laboratory study included in this dataset, the average sRD value from the plateau region of the highest food-level treatment at each temperature was used. In 3 studies (all warmwater species), RD values continually increased throughout the reported sampling period (Westerman \& Holt 1994, Rossi-Wongtschowski et al. 2003, Holt et al. unpubl.). For those studies, the sRD value from the last sampling day was used. To ensure that the sRD

Table 2. Sources of RD (RNA/DNA ratio of whole larval fish), temperature and growth rate data used in the meta-analysis. dph = days post hatch

\begin{tabular}{|c|c|c|c|c|c|c|c|}
\hline Species & $\begin{array}{l}\text { Common } \\
\text { name }\end{array}$ & $\begin{array}{c}\text { Age range } \\
\text { of } \\
\text { larvae } \\
\text { (dph) }\end{array}$ & $\begin{array}{c}\text { Nominal } \\
\text { temperature } \\
\left({ }^{\circ} \mathrm{C}\right)\end{array}$ & $\begin{array}{c}\text { Ratio of } \\
\text { slopes of } \\
\text { standard curves } \\
\left(\mathrm{m}_{\mathrm{DNA}}: \mathrm{m}_{\mathrm{RNA}}\right)\end{array}$ & $\begin{array}{l}\text { No. of d } \\
\text { in dat } \\
\text { Growth- } \\
\text { model }\end{array}$ & $\begin{array}{l}\text { ta points } \\
\text { set } \\
\text { Well-fed- } \\
\quad \text { fish }\end{array}$ & Source \\
\hline \multirow[t]{2}{*}{ Clupea harengus } & Herring & $5-27$ & $5,8,11$ & 2.20 & 6 & 0 & $\begin{array}{l}\text { Suneetha et al. } \\
\text { (1999) }\end{array}$ \\
\hline & & $6-24$ & $\begin{array}{l}5,6,8,11 \\
12,13,14\end{array}$ & 2.20 & 13 & 0 & $\begin{array}{l}\text { Clemmesen et al. } \\
\text { (unpubl.) }\end{array}$ \\
\hline \multirow[t]{4}{*}{ Gadus morhua } & Baltic cod & $7-17$ & 8 & 2.33 & 1 & 1 & $\begin{array}{l}\text { Grønkjær et al. } \\
(1997)\end{array}$ \\
\hline & North Sea cod & $6-16$ & 8 & 2.33 & 5 & 0 & $\begin{array}{l}\text { St. John et al. } \\
(2001)\end{array}$ \\
\hline & Atlantic cod & $6-40$ & $3,6,9$ & 2.60 & 12 & 3 & $\begin{array}{l}\text { Caldarone et al. } \\
\text { (2003) }\end{array}$ \\
\hline & $\begin{array}{l}\text { Norwegian coastal } \\
\text { cod }\end{array}$ & l $8-48$ & 10 & 2.20 & 1 & 1 & $\begin{array}{l}\text { Skajaa et al. } \\
(2003)\end{array}$ \\
\hline $\begin{array}{l}\text { Melanogrammus } \\
\text { aeglefinus }\end{array}$ & Haddock & $8-48$ & $6,8,10$ & 2.68 & 12 & 3 & $\begin{array}{l}\text { Caldarone } \\
(2005)\end{array}$ \\
\hline $\begin{array}{l}\text { Sardinella } \\
\text { brasiliensis }\end{array}$ & Brazilian sardine & $4-13$ & 23 & 2.25 & 1 & 1 & $\begin{array}{l}\text { Rossi-Wongtschowski } \\
\text { et al. (2003) }\end{array}$ \\
\hline \multirow[t]{2}{*}{$\begin{array}{l}\text { Sardinops } \\
\text { melanostictus }\end{array}$} & Japanese sardine & $3-15$ & 19 & 1.49 & 1 & 0 & $\begin{array}{l}\text { Sato et al. } \\
(1995)\end{array}$ \\
\hline & & $3-8$ & 16 & 1.75 & 1 & 1 & $\begin{array}{l}\text { Kimura et al. } \\
(2000)\end{array}$ \\
\hline \multirow[t]{3}{*}{$\begin{array}{r}\text { Sciaenops } \\
\text { ocellatus }\end{array}$} & Red drum & $1-14$ & 28 & 3.55 & 1 & 0 & $\begin{array}{l}\text { Westerman \& Holt } \\
\text { (1994) (group 1) }\end{array}$ \\
\hline & & $1-14$ & 28 & 3.55 & 1 & 1 & $\begin{array}{l}\text { Westerman \& Holt } \\
\text { (1994) (group 2) }\end{array}$ \\
\hline & & $11-26$ & 23,28 & 5.63 & 2 & 1 & $\begin{array}{l}\text { Holt et al. } \\
\text { (unpubl.) }\end{array}$ \\
\hline $\begin{array}{l}\text { Theragra } \\
\text { chalcogramma }\end{array}$ & Walleye pollock & $7-16$ & 6 & 2.81 & 4 & 1 & Canino (1997) \\
\hline Total & & & & & 55 & 13 & \\
\hline
\end{tabular}


values were associated with well-growing fish, only data from larvae exhibiting growth rates $\geq$ rates predicted by Houde \& Zastrow's (1993) growth equation for marine fish were included.

The growth model data set was used to construct growth models relating sRD and T to G. We used an information-theoretic approach (Akaike's information criterion, AIC) for selecting the 'best-fit' model (Wagenmakers \& Farrell 2004). Plots of residuals from the model were examined for any trends. The well-fed fish data set was used to compute a Pearson product moment correlation between sRD and T. Data were analyzed using SAS software v8.02.

Additionally, in order to reanalyze results from a published larval Atlantic cod Gadus morhua and haddock Melanogrammus aeglefinus RD-T-G study (Caldarone 2005), RD values from that study were converted to sRD values using 2.4 as the reference slope-ratio value. The SRD values were then used to recompute the multiple linear regression model published in the study. The sRD data were also fit to new models containing a $\mathrm{SRD} \times \mathrm{T}$ interaction term.

An independent data set (data which were not used in the model calculations) consisting of measured growth rates and RD values of herring (Clupea harengus, Hauss 2008) was used to test the fit of the metaanalysis growth model determined in the present study. The data set consisted of larvae reared at 2 temperatures $\left(7^{\circ} \mathrm{C}, \mathrm{n}=302\right.$; and $\left.13^{\circ} \mathrm{C}, \mathrm{n}=147\right)$ and sampled twice: initially, and after 50 degree days. Growth rates were calculated based on dry weight and Eq. (1). Nu- cleic acids were analyzed with a 1-dye fluorometric assay (modified after Clemmesen 1993 and Belchier et al. 2004) with the ratio of the slopes of the standards being 2.2. $\mathrm{RD}$ values were standardized as outlined above.

\section{RESULTS}

Eleven published studies and 2 manuscripts in preparation met the criteria for inclusion in the combined data set (Table 2). Two subsets of this data were

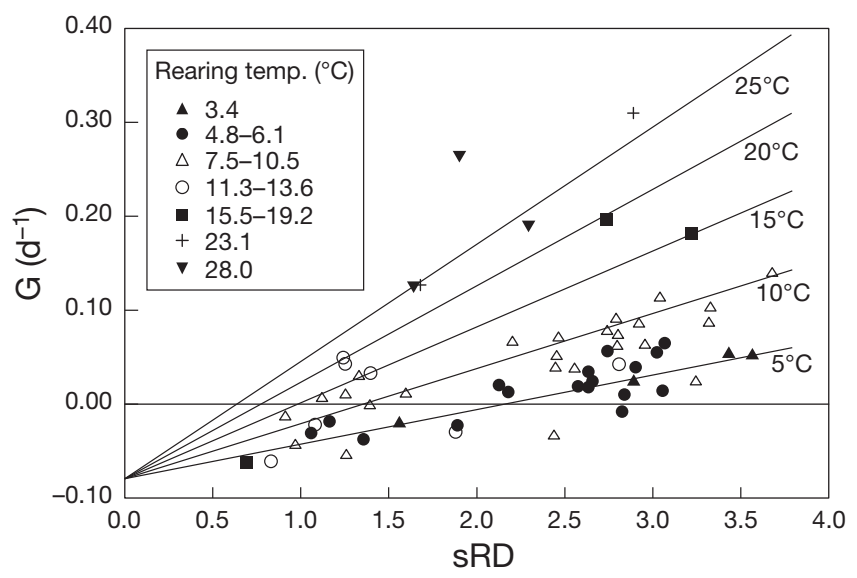

Fig. 1. Relationship between observed instantaneous growth rates $(\mathrm{G})$ and standardized RNA/DNA ratios (sRD) of larvae in the growth model data set (Table 2). Data points are grouped by rearing temperature. The regression lines are predicted from the best-fit meta-analysis growth model (Eq. 1 in Table 3)

Table 3. Coefficients $( \pm \mathrm{SE})$ and Akaike's second-order information criterion (AIC) of the regression models of growth rate $(\mathrm{G}$, $\mathrm{d}^{-1}$ ). For all models, $\mathrm{p} \leq 0.0001 ; \mathrm{sRD}=$ standardized RNA/DNA ratio, $\mathrm{T}=$ environmental temperature $\left({ }^{\circ} \mathrm{C}\right), \mathrm{sRD} \times \mathrm{T}=\mathrm{interaction}$ of sRD and T, $F=F$-test statistic, $K=$ number of parameters, $\triangle \mathrm{AIC}=$ difference in AIC with respect to the best candidate model, and $w_{i}(\mathrm{AIC})=$ Akaike weight (model probability). Equations are ranked by increasing AIC values

\begin{tabular}{|c|c|c|c|c|c|c|c|c|c|c|}
\hline \multirow{2}{*}{$\begin{array}{l}\text { Equation } \\
\text { no. }\end{array}$} & \multirow[b]{2}{*}{ sRD } & \multicolumn{2}{|c|}{ Parameters } & \multirow[b]{2}{*}{ Intercept } & \multirow[t]{2}{*}{$r^{2}$} & \multirow[t]{2}{*}{$F$} & \multirow[t]{2}{*}{$K$} & \multirow[t]{2}{*}{ AIC } & \multirow{2}{*}{$\Delta \mathrm{AIC}$} & \multirow{2}{*}{$w_{i}(\mathrm{AIC})$} \\
\hline & & $\mathrm{T}$ & $\mathrm{sRD} \times \mathrm{T}$ & & & & & & & \\
\hline \multicolumn{11}{|c|}{ Multi-species growth-model data set, $n=61$} \\
\hline 1 & $0.0145 \pm 0.0054$ & & $0.0044 \pm 0.0003$ & $-0.0780 \pm 0.0123$ & 0.818 & 130 & 3 & -417 & 0 & 0.561 \\
\hline 2 & & $-0.0027 \pm 0.0012$ & $0.0056 \pm 0.0005$ & $-0.0449 \pm 0.0082$ & 0.811 & 125 & 3 & -415 & 2 & 0.206 \\
\hline 3 & $0.0168 \pm 0.0120$ & $0.0006 \pm 0.0023$ & $0.0041 \pm 0.0012$ & $-0.0836 \pm 0.0289$ & 0.818 & 85 & 4 & -415 & 2 & 0.183 \\
\hline 4 & & & $0.0047 \pm 0.0003$ & $-0.0520 \pm 0.0078$ & 0.795 & 229 & 2 & -412 & 5 & 0.051 \\
\hline 5 & $0.0556 \pm 0.0057$ & $0.0095 \pm 0.0008$ & & $-0.1715 \pm 0.0169$ & 0.777 & 101 & 3 & -405 & 12 & \\
\hline 6 & & $0.0080 \pm 0.0013$ & & $-0.0311 \pm 0.0143$ & 0.409 & 41 & 2 & -348 & 70 & \\
\hline 7 & $0.0424 \pm 0.0103$ & & & $-0.0485 \pm 0.0248$ & 0.222 & 17 & 2 & -331 & 86 & \\
\hline \multicolumn{11}{|c|}{ Combined cod and haddock data set, $n=172$} \\
\hline 8 & $0.0254 \pm 0.0059$ & & $0.0037 \pm 0.0005$ & $-0.0873 \pm 0.0136$ & 0.479 & 78 & 3 & -1135 & 0 & \\
\hline 9 & $0.0242 \pm 0.0129$ & $-0.0006 \pm 0.0049$ & $0.0039 \pm 0.0018$ & $-0.0837 \pm 0.0349$ & 0.479 & 52 & 4 & -1133 & 2 & \\
\hline 10 & & $-0.0087 \pm 0.0023$ & $0.0070 \pm 0.0007$ & $-0.0210 \pm 0.0099$ & 0.469 & 75 & 3 & -1132 & 3 & \\
\hline 11 & $0.0492 \pm 0.0051$ & $0.0094 \pm 0.0013$ & & $-0.1486 \pm 0.167$ & 0.466 & 74 & 3 & -1131 & 4 & \\
\hline 12 & & & $0.0047 \pm 0.0004$ & $-0.0408 \pm 0.0088$ & 0.422 & 125 & 2 & -1119 & 16 & \\
\hline 13 & $0.0493 \pm 0.0058$ & & & $-0.0793 \pm 0.0157$ & 0.296 & 72 & 2 & -1085 & 50 & \\
\hline 14 & & $0.0095 \pm 0.0016$ & & $-0.0184 \pm 0.0123$ & 0.171 & 35 & 2 & -1057 & 78 & \\
\hline
\end{tabular}


used for subsequent calculations: the growth model data set and the well-fed fish data set. The growth model data set consisted of 61 data points from 13 studies with sRD values ranging from 0.7 to 3.7 , and instantaneous growth rates ranging from -0.06 to 0.31 at temperatures ranging from 3 to $28^{\circ} \mathrm{C}$. The 7 species in this data set included starved larvae, larvae on restricted rations, and well-fed larvae on a variety of different diets (rotifers and wild plankton). Approximately $83 \%$ of the data encompassed growth rates determined from 3 to $4 \mathrm{~d}$ growth intervals. A plot of the raw data (Fig. 1) indicated that the slopes of the sRD-G relationship differed between temperatures, suggesting that an interaction term $(\mathrm{sRD} \times \mathrm{T})$ might be necessary in the models. Therefore, growth models containing all linear combinations of $\mathrm{SRD}, \mathrm{T}$, and $\mathrm{sRD} \times \mathrm{T}$ were examined (Table 3 ). Based on the AIC values, the best-fit model for the growth data includes the interaction term, a sRD main effect term, and an intercept (Eq. 1 in Table 3). The results of the Akaike weights indicate that given the data available, there is a $56 \%$ probability that this model is the best out of the set of models tested. Based on the evidence ratio (ratio of Akaike weights, $w_{j} / w_{i}$ ), this model is $\sim 3 \times$ more likely to be the best model compared to the 2 next best models. A plot of the observed growth rate versus the growth rate estimated by this model suggests that the model fits the data well over the whole range of observed growth rates, including starved larvae (Fig. 2). Analysis of residuals suggests that the relationship is applicable over both the SRD and temperature ranges studied (plots not shown). Residuals from

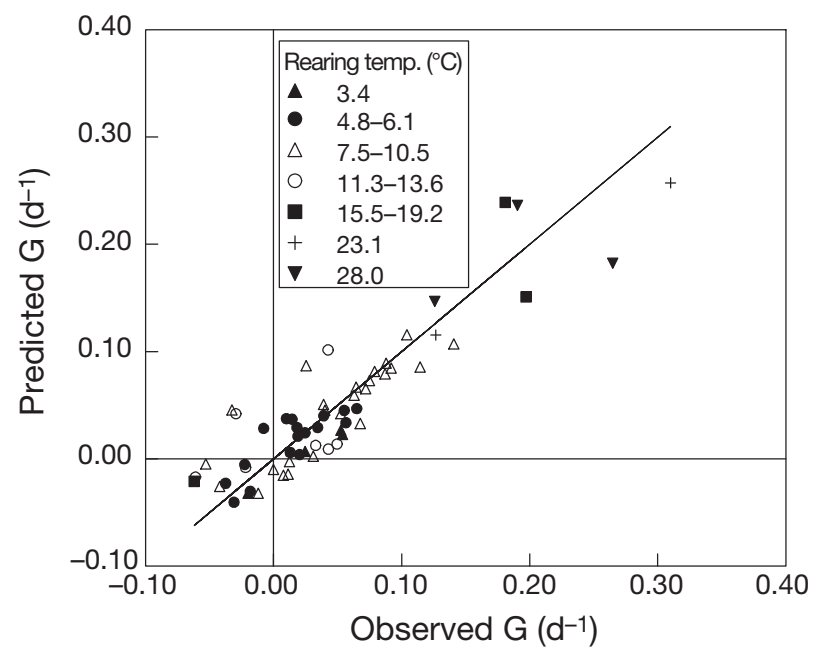

Fig. 2. Relationship between observed instantaneous growth rates $(G)$ of larvae in the growth model data set and growth rates estimated with the best-fit meta-analysis growth model (Eq. 1 in Table 3). The line represents a 1:1 relation. Data points are grouped by rearing temperature

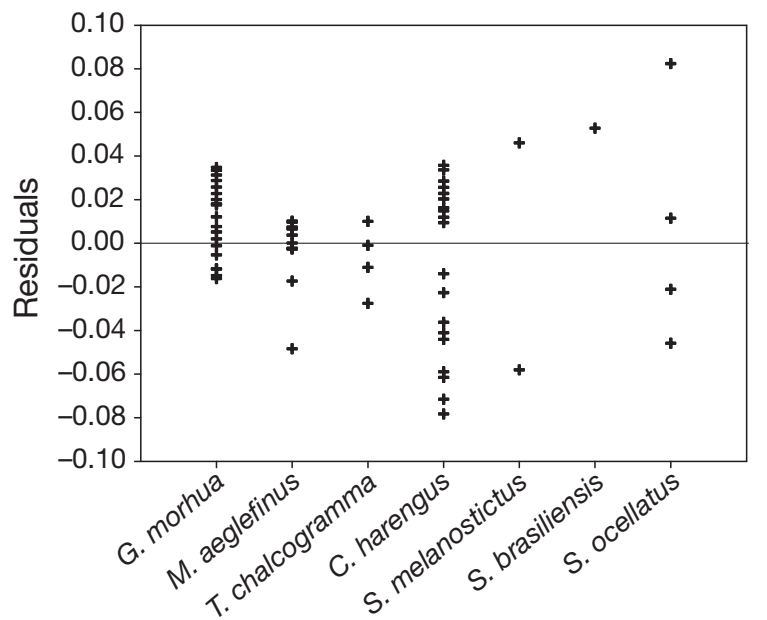

Fig. 3. Residuals from the best-fit meta-analysis growth model (Eq. 1 in Table 3) in relation to fish species using the growth model data set (Table 2). Full species' names in Table 2

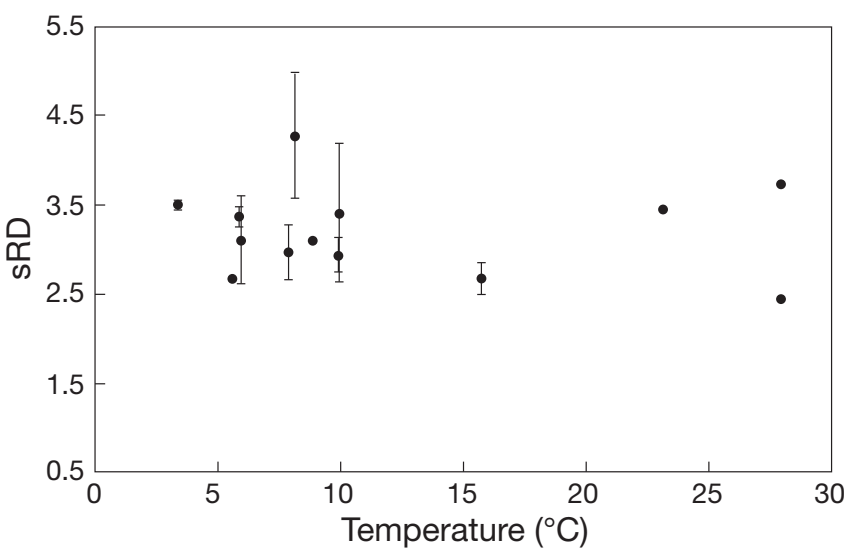

Fig. 4. Standardized RNA/DNA ratios (sRD, $\pm 1 \mathrm{SD}$ ) of wellfed marine fish larvae (well-fed fish data set) in relation to temperature. The $y$-axis encompasses the range of $\mathrm{sRD}$ values found in both the growth model and well-fed fish data sets (Table 2)

the model plotted against species showed no clear outliers (Fig.3).

The well-fed fish data set consisted of 13 data points from 9 studies. The 6 species in this data set were considered to be 'well-fed' by the authors of the studies. Although the SRD data showed considerable variability, no trend in the values with temperature (Fig. 4) (Pearson correlation coefficient $\mathrm{r}=-0.102 ; \mathrm{p}=0.74$ ) was observed. The mean of the sRD values was $3.20 \pm$ 0.49 .

After standardizing the RD values, data from calibration experiments with Atlantic cod and haddock (Caldarone et al. 2003, Caldarone 2005) were reanalyzed and models containing all linear combinations of SRD, $\mathrm{T}$, and $\mathrm{sRD} \times \mathrm{T}$ were constructed (Table 3 ). Based on 


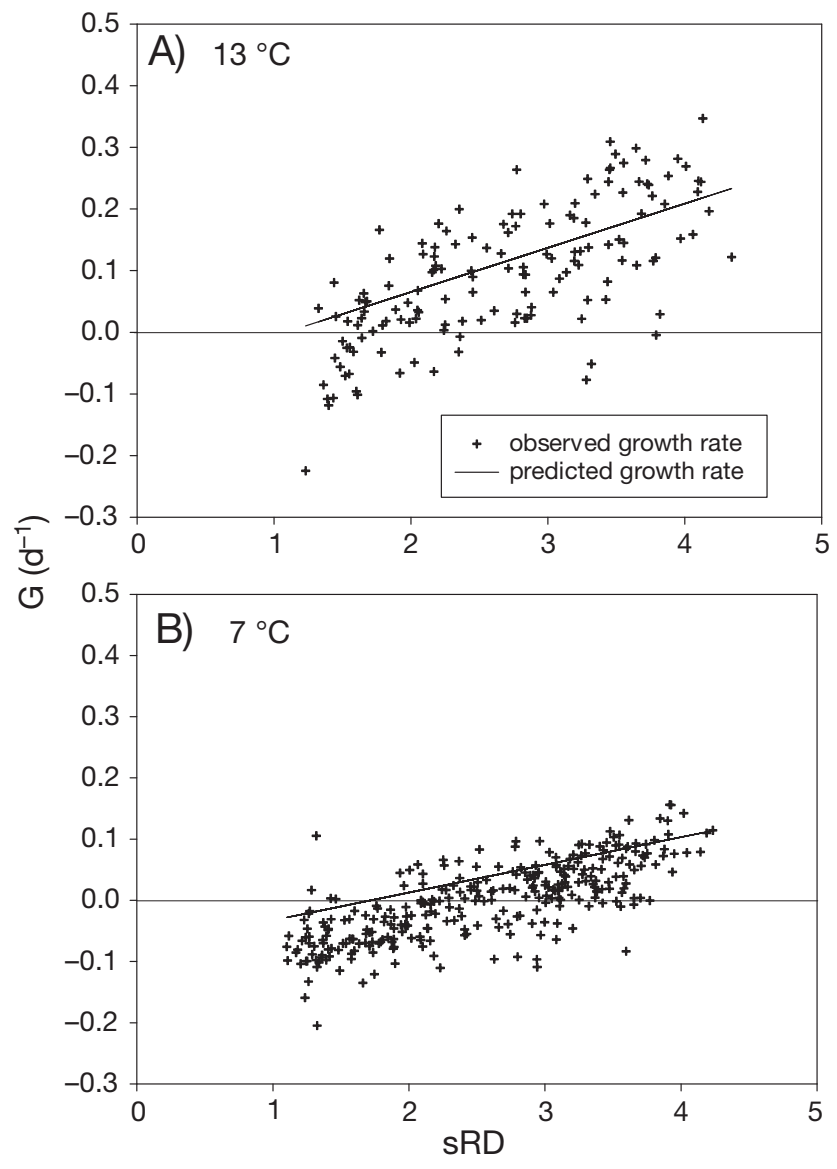

Fig. 5. Clupea harengus. Relationship between observed instantaneous growth rates (G) from an independent data set (Hauss 2008) and growth rates estimated with the metaanalysis growth model (Eq. 1 in Table 3). (A) Herring reared at $13^{\circ} \mathrm{C}$, and $(\mathrm{B})$ herring reared at $7^{\circ} \mathrm{C} . \mathrm{sRD}=$ standardized RNA/DNA ratio

AIC, the best combined cod and haddock model included the main effect of sRD, the interaction term, and an intercept (Eq. 8 in Table 3). When growth rates calculated with the original published model (Eq. 11 in Table 3 ) and the AIC best-fit model (Eq. 8 in Table 3) were compared, no significant difference was found (paired $t$-test; $\mathrm{n}=172, \mathrm{p}=0.99$ ).

At $13^{\circ} \mathrm{C}$, measured growth rates for herring from the independent data set (Hauss 2008) ranged from -0.22 to $0.35 \mathrm{~d}^{-1}$. At this temperature, larval growth rates estimated with the best-fit meta-analysis growth model (Eq. 1 in Table 3) fit the raw data well (average residual -0.018 , Fig. 5A). The herring reared at $7^{\circ} \mathrm{C}$ had a much narrower range of measured growth rates $\left(-0.20\right.$ to $\left.0.16 \mathrm{~d}^{-1}\right)$ and a higher percentage of negative growth rates than their $13^{\circ} \mathrm{C}$ counterparts (35 vs. $9 \%$ ). Estimated growth rates for the $7^{\circ} \mathrm{C}$ larvae were larger than most of the observed values (average residual -0.038 , Fig. 5B).

\section{DISCUSSION}

\section{Growth estimates}

Because methodological details can affect the estimate of $\mathrm{RD}$, any raw $\mathrm{RD}$ data derived from differing analytical protocols must first be standardized before it can be used in a meta-analysis. The fluorometric standardization method outlined in Caldarone et al. (2006) is limited to nucleic acids determined with 1-dye spectrofluorometric procedures where either the ratios of the slopes of the standards are consistent between analysis dates within the study, or the individual runs are standardized to a consistent slope ratio. Data from 2-dye spectrofluorometric nucleic acid analyses can not be standardized using this method and were thus not included. Data was also limited to whole larvae RD to eliminate variability due to values derived from different tissues (Houlihan et al. 1988, Fernandez 1997). Working within these constraints, we were able to obtain data from a variety of larval fish species residing in a range of temperatures and fed different rations, resulting in a range of growth rates.

Few studies that define the relationship between RD, $\mathrm{T}$ and $\mathrm{G}$ in larval fish have been conducted. To date, all of the published models have been multiple linear regressions of the form:

$$
\mathrm{G}=\mathrm{m}_{1} \times \mathrm{RD}+\mathrm{m}_{2} \times \mathrm{T}+\mathrm{C}_{1}
$$

where $\mathrm{G}$ is the growth rate expressed either as an instantaneous weight- or protein-specific growth rate or in percent $\left(\mathrm{G}_{\%}\right), \mathrm{RD}$ is the whole-body ratio of RNA to DNA, $\mathrm{T}$ is the rearing temperature in ${ }^{\circ} \mathrm{C}, \mathrm{m}_{1}$ and $\mathrm{m}_{2}$ are coefficients, and $\mathrm{C}_{1}$ is a constant (Table 1). These calibration models were mostly derived for single coolwater species reared at temperatures they normally encounter in the wild, which usually encompassed a range $<7^{\circ} \mathrm{C}$. In most instances, the addition of terms for larval age, size, or feeding level to these models did not significantly decrease the residual sum of squares, indicating that the relationship among $\mathrm{RD}, \mathrm{T}$ and $\mathrm{G}$ was independent of these variables (e.g. Buckley 1982, Caldarone et al. 2003, Caldarone 2005); i.e. while RD and $\mathrm{G}$ are known to follow ontogenetic trends (e.g. Buckley et al. 2006, Malzahn et al. 2007, Clemmesen et al. unpubl.), the RD-T-G relationship appears stable during the larval stage.

We initially fit the data from the growth model data set to a multiple linear regression model similar in form to the previously published models (Eq. 5 in Table 3). However, the plot of our meta-analysis data (Fig. 1), which included data from a much wider range of temperatures than could be tested within a single species, indicated that an interaction term between SRD and T $(\mathrm{sRD} \times \mathrm{T})$ should be tested as a possible variable. 
Therefore, growth models containing all linear combinations of $\mathrm{sRD}, \mathrm{T}$, and $\mathrm{sRD} \times \mathrm{T}$ were examined (Table 3). The model with the lowest AIC value included the interaction term, a sRD main effect term, and an intercept (Eq. 1 in Table 3). With this model, lines of constant temperature in RD-G space meet at $G=-0.078$, with their slopes increasing as temperature increases. A plot of the observed growth rate versus the growth rate estimated with this equation suggests that the model fits the data well over the whole range of observed growth rates, including starved larvae (Fig. 2). Analysis of residuals suggests that the relationship is applicable over the sRD and temperature range studied; however, for a given species, the model is only applicable for temperatures within the range of tolerance of that species.

Data from a previously published RD-T-G study of larval Atlantic cod and haddock was never fit to models containing an interaction term (Caldarone 2005). When this term was tested, the best fit model based on AIC included the main effect of sRD and the interaction term (Eq. 8 in Table 3 ). However, over the range of temperatures used in the experiments $\left(3\right.$ to $10^{\circ} \mathrm{C}$ ), estimates of $\mathrm{G}$ from the previously published model (Eq. 11 in Table 3) were not statistically significantly different from the best-fit model containing the interaction term.

Interestingly, while to our knowledge a larval fish RD-T-G relationship with an interaction term has not been previously published, there are 2 papers reporting such a model for copepods (Saiz et al. 1998, Wagner et al. 2001). The good fit of the proposed model (Eq. 1 in Table 3) to 7 species also demonstrates an underlying similarity among fishes. Protein synthesis and the ribosomal machinery develop very early in the history of life. Ribosomal RNA sequences are highly conserved across species (Mindell \& Honeycutt 1990). It should be expected, or at least not unexpected, that a single equation can describe the relationship among $\mathrm{sRD}, \mathrm{T}$ and $\mathrm{G}$ in a single life stage across a closely related group of species (temperate marine fish). The possibility of this general relationship was already indicated by Buckley (1984) who found that a single equation adequately described the RD (measured using an UV procedure)-T-G relationship in larvae of 8 species of temperate marine fishes reared in his laboratory. The novelty of the present study comprises the (1) inclusion of warmer water species, thus expanding the temperature range analyzed, (2) inclusion of data obtained from different laboratories, and (3) development of a model which can be used by researchers analyzing nucleic acids with newer fluorometric techniques. Given the variety of fish species included in this new model, and the overall good fit given the many possible sources of variability among the growth estimates, nucleic acid analytical procedures and laboratories; it appears that use of this best-fit model of the sRD-T-G relationship should yield reasonable estimates of larval $\mathrm{G}$ regardless of the temperate fish species under consideration. Ideally, the RD-T-G relationship should be determined for the species of interest; however, this approach which has been undertaken by only a few researchers (perhaps due to its cost, labor intensiveness and requirement for specialized temperature-controlled rearing facilities) may not be absolutely necessary, as the meta-analysis data shows.

An independent verification of the best-fit metaanalysis model is the similarity between growth rates estimated with the model and those observed in herring reared at $13^{\circ} \mathrm{C}$ from the Hauss (2008) data set (Fig. 5A). The scatter of the observed growth rates around the estimated rate is most likely due to imprecision in the measurement of larval growth rate. Ideally, growth rates should be determined by measuring the change in size (protein, dry weight) of each individual. Due to the destructive nature of this method, the initial size of a larva must be estimated from the mean of a pool of larvae. However, the mean initial size is unlikely to be an accurate estimate of the individual's initial size, given the wide range in size of larvae at a given age. At $7^{\circ} \mathrm{C}$, although the model growth estimates fit the trend in the data well, the values appear to be offset by a constant amount. More laboratory RD-growth experiments especially conducted at warmer temperatures would aid in further evaluating the best-fit meta-analysis model.

\section{Effect of fish size and temperature on the use of RD as a condition index}

There is a large body of literature reporting RD values of fish collected in different habitats (e.g. Canino et al. 1991, Canino 1997, Clemmesen et al. 1997, Rooker et al. 1997, Kimura et al. 2000, Chícharo et al. 2003, Catalan et al. 2006, Garcia et al. 2006, Lee et al. 2006, Malzahn et al. 2007). When fish size and water temperature between sites are similar, interpretation of results is straightforward: the group with the higher $\mathrm{RD}$ is in better condition since it contains more machinery (potential) for protein synthesis. Interpretation of results is more problematic when size or water temperatures differ among sites. Both field and laboratory studies with well-fed fish indicate that, after initiation of exogenous feeding, growth rate is size dependent. Studies have shown a rapid initial increase in recent growth rate with larval size, followed by a more gradual increase (Otterlei et al. 1999, Buckley et al. 2006). Since the RD-T-G relationship is applicable over the 

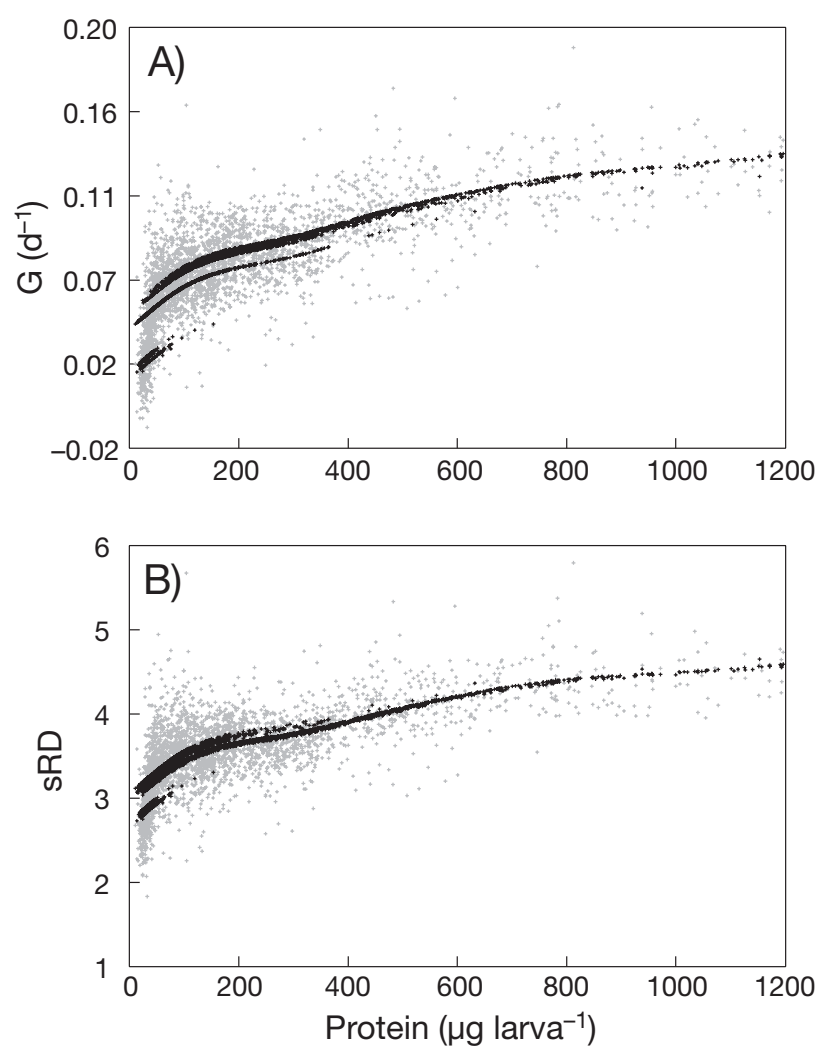

Fig. 6. Melanogrammus aeglefinus. Larval data $(\mathrm{n}=2911)$ collected on Georges Bank in March, April and May 1999 (Buckley et al. 2006). Size-dependent trends of larvae with $<1200 \mu \mathrm{g}$ protein were fit to a size- and photoperiod-dependent model: $\mathrm{G}$ or $\mathrm{sRD}=$ spline (protein content, $\mathrm{df}=4$ ) spline (photoperiod, $\mathrm{df}=4$ ) using the SAS GAM procedure for nonparametric regression. Relationship between larval size $(\mu \mathrm{g}$ protein larva ${ }^{-1}$ ) and (A) instantaneous growth rate $\left(G, d^{-1}\right)$, and (B) sRD. The average ratio of the slopes of the standards for the data set was equal to the reference slope-ratio value $(2.4)$; therefore RD values equaled sRD values without any conversion. Predicted growth rates (black) in (A) are from the size- and photoperiod-dependent growth model (SPPDG); the 3 curves from bottom to top are predicted $\mathrm{G}$ for larvae on March 15 (12.8 h photoperiod [PP]), April 15 (14.3 h PP) and May 15 (15.5 h PP). Predicted sRD values (black) in (B) are from the size- and photoperiod-dependent sRD model. Predicted values for April and May (top 2 curves) are very similar. $\mathrm{sRD}=$ standardized RNA/DNA ratio

entire larval stage, it follows that as G increases with larval size, so do RD values. Thus, for example, a fish in optimal condition at $25 \mathrm{~d}$ post hatch (dph) would be expected to have a greater $\mathrm{G}$ and RD than one in optimal condition at $5 \mathrm{dph}$. Examples of size-dependent trends of $\mathrm{G}$ and RD in haddock larvae collected from Georges Bank during our GLOBEC study are illustrated in Fig. 6. The year 1999 was selected since food was plentiful in that year and process cruises were completed in 3 consecutive months - March, April and May.
Numerous published results from single-species studies and meta-analyses (e.g. Pepin 1991, Houde \& Zastrow 1993) indicate that the growth rate of temperate marine fish larvae is also temperature dependent. But, what about RD values - are they also temperature dependent? Or is the increase in G with temperature accomplished solely through an increase in activity rather than an increase in the amount of RNA. Available sRD data for well-fed larvae (well-fed fish data set) showed considerable variability, but no trend in the SRD values with temperature was noted (Fig. 4). Much of the scatter around the mean (3.20) was likely due to a number of sources in addition to any speciesspecific effect, including differences in food quality, rearing conditions, analytical procedures, and the age or size of the larvae, although we attempted to minimize the effects of these variables (see 'Methods'). The tight coupling among RD, T and G during the larval stage of marine fishes suggests that over periods of a few days or less adjustments in the concentration rather than changes in the activity or efficiency of RNA plays a larger role in acclimation to feeding conditions. Moreover, the lack of a trend in sRD of wellfed larvae with rearing temperature suggests that at least in well-fed fish any temperature-driven increase in growth rate is accomplished through an increase in the activity rather than an increase in the concentration of RNA.

It would follow, then, that for larvae that are not food limited, direct comparison of the RD values could be made regardless of the environmental temperature. In fact, they should have the same $\mathrm{sRD}$ value $\left(\mathrm{RD}_{\max }\right)$. Based on (1) the difficulty of maintaining optimal culture conditions in the laboratory, (2) the scatter we observed in sRD values (Fig. 4), and (3) comparison with field data (Fig. 6), it appears that the mean sRD value from our well-fed fish data set (3.2) is likely an underestimate and does not represent the sRD of larvae exhibiting unconstrained growth $\left(\mathrm{RD}_{\max }\right)$. Field samples from our GLOBEC study (Buckley et al. 2006) suggest that the size-dependent $\mathrm{RD}_{\max }$ approaches a SRD value of about 4.4 for both Atlantic cod and haddock (Fig. 6). This higher value may also be a result of predators in the field selectively removing slower growing individuals in a cohort (Nielsen \& Munk 2004), a circumstance not encountered in laboratory studies.

If condition is defined simply as the amount of protein synthetic machinery per cell, then sRD values of larvae of similar size could be compared across temperatures. This approach is supported by the idea that if the larvae were brought to a common temperature, the group with the higher RD value would grow faster. However, although our data from fully fed fish suggests that RD values may in fact be temperature inde- 
pendent, the best-fit meta-analysis model does not support this conclusion in fish less than fully fed. This aspect is discussed more fully in the following 2 sections.

\section{Estimating growth performance and reference growth rates}

Growth performance $\left(\mathrm{G}_{\mathrm{pf}}\right)$, the quotient of the observed growth rate $(\mathrm{G})$ and the growth rate achieved by larva of a given size at a given temperature and photoperiod under optimal feeding and environmental conditions $\left(\mathrm{G}_{\max }\right)$, provides an objective measure of larval condition. $G$ could be estimated from RD and $T$, or alternatively from otolith microstructure analysis. However, the effects of temperature, larval size and other factors need to be considered when determining $G_{\text {max }}$. Having a $G_{\text {max }}$ model for each species, or a generalized $\mathrm{G}_{\max }$ model based on multiple species, would be ideal. But given the difficulty in determining this value, an alternative approach would be to compare the calculated growth rates to some standard or reference growth rate $\left(\mathrm{G}_{\mathrm{ref}}\right)$.

The available literature provides several options for estimating $\mathrm{G}_{\text {ref }}$. Houde \& Zastrow (1993) published a multi-species model based on a compilation of published data from 80 marine and estuarine species. The relationship between the midpoint of $\mathrm{G}$ and the midpoint of $\mathrm{T}$ was fit to the equation:

$$
\mathrm{G}=0.0106 \times \mathrm{T}-0.0203
$$

for $\mathrm{n}=80, \mathrm{r}^{2}=0.35$, and $\mathrm{p}<0.0001$ (corrected equation, E.D. Houde pers. comm.). This $\sim 1 \% \mathrm{~d}^{-1}$ increase in weight-specific growth rate for each $1^{\circ} \mathrm{C}$ increase in temperature has also been seen across species (metaanalysis) in other studies, with optimal temperatures ranging from 5 to $30^{\circ} \mathrm{C}$ (Morse 1989, Pepin 1991, Houde \& Zastrow 1993). For individual species within their optimal temperature range, the rate of increase in weight-specific growth rate with temperature appears to vary somewhat with species and stock, but is still generally close to $1 \% \mathrm{~d}^{-1}$. While Eq. (3) provides an estimate of the effect of temperature on $\mathrm{G}$ in feeding larvae across species, $G$ estimated using this equation is $<\mathrm{G}_{\max }$, since larvae fed at reduced ration were included in the analysis. Additionally, no adjustment was made for the effect of larval size on $\mathrm{G}$.

Folkvord (2005) presented single-species size (dry weight, DW)- and temperature-dependent growth models (STDG) based on well-fed Atlantic cod larvae reared in the laboratory. He used the model for the fastest growing stock (Norwegian coastal cod, NC) to estimate reference growth rates against which cod growth performance could be measured, as follows:
$\mathrm{G}_{\%}=1.20+1.80 \times \mathrm{T}-0.078 \times \mathrm{T} \times \operatorname{lnDW}-0.0946 \times \mathrm{T} \times$

$(\operatorname{lnDW})^{2}+0.0105 \times \mathrm{T} \times(\operatorname{lnDW})^{3}$

Buckley et al. (2006) suggested that the ambient photoperiod should also be considered when estimating $\mathrm{G}_{\text {ref }}$ since photoperiod affects growth potential by delimiting the duration of daily feeding . A reanalysis of a subset of the Georges Bank Atlantic cod and haddock data set, limited to a time period when suitable prey items appeared to be present in abundance (March through May 1999, Buckley \& Durbin 2006), yields the following size (protein, Pro)-, temperature-, and photoperiod (PP)-dependent growth rate (STPDG) model:

$\mathrm{G}=0.01512 \ln ($ Pro $)+0.00686 \times \mathrm{T}+0.00285 \times \mathrm{PP}-$ 0.08810

for $\mathrm{n}=5262, \mathrm{r}^{2}=0.636$, and all parameters significant at $\mathrm{p}<0.0001$. This Atlantic cod and haddock STPDG model produces estimates of $\mathrm{G}$ similar to that of Folkvord's Atlantic cod STDG models but includes an adjustment for photoperiod (Buckley et al. 2006).

The utility of using $\mathrm{G}$ calculated from any of the previous 3 models (Eqs. 3 to 5 ) as an estimate of $G_{\text {ref }}$ across species has yet to be tested, but until more general models are available, they may prove useful for estimating reference growth rates that account for the effects of temperature, size, and photoperiod. An estimated $\mathrm{G}_{\mathrm{pf}}$ can then be calculated by dividing observed growth rates derived from sRD values or other means, by these $\mathrm{G}_{\text {ref }}$.

\section{RD, growth performance and temperature}

From a convenience point of view, a RD-T-G model for which $\mathrm{G}_{\mathrm{pf}}$ was independent of $\mathrm{T}$ would be highly desirable as it would allow direct comparison of sRD values as a condition index regardless of temperature and nutritional condition. With this goal in mind we considered several G models (not shown in Table 3) where the temperature term drops out in the $\mathrm{G}_{\mathrm{pf}}$ calculation. One such model is $\mathrm{G}=\mathrm{m}_{1} \times\left(\mathrm{sRD}-\mathrm{sRD}_{\mathrm{m}}\right) \times \mathrm{T}$ where $\mathrm{sRD}_{\mathrm{m}}$ is the (standardized) amount of RNA required for maintenance. Our reasoning was that sRDm was independent of temperature because higher maintenance costs at higher temperatures would be balanced out by higher RNA activity. This model is mathematically equivalent to $\mathrm{G}=\mathrm{m}_{1} \times \mathrm{T}+\mathrm{m}_{2} \times \mathrm{T} \times \mathrm{sRD}$ with an intercept of zero. This model gave an $\mathrm{r}^{2}=0.77$ for the multi-species growth model data set and an $\mathrm{r}^{2}=$ 0.46 for the combined cod and haddock data set. These $\mathrm{r}^{2}$ are lower than those of the best-fit models in Table 3, but the zero intercept model has one less parameter. 
Table 4. Estimated growth rate $\left(\mathrm{G}, \mathrm{d}^{-1}\right)$ and growth performance $\left(\mathrm{G}_{\mathrm{pf}}\right)$ for a range of sRD and temperature values. $\mathrm{G}$ is calculated using the best-fit meta-analysis growth model (Eq.1 in Table 3). For illustrative purposes, $\mathrm{G}_{\mathrm{pf}}$, the fraction of maximum growth realized (\%) is set to 100 at a sRD value of 4.5 , which is an estimated sRD value for a single size class of larvae growing under optimal conditions (fully fed). $\mathrm{sRD}=$ standardized RNA/DNA ratio, $\mathrm{T}=$ temperature

\begin{tabular}{|cccc|}
\hline sRD & $\mathrm{T}\left({ }^{\circ} \mathrm{C}\right)$ & $\mathrm{G}\left(\mathrm{d}^{-1}\right)$ & $\mathrm{G}$ \\
\hline 4.5 & 25 & 0.479 & 100 \\
& 20 & 0.383 & 100 \\
& 15 & 0.282 & 100 \\
& 10 & 0.184 & 100 \\
& 5 & 0.085 & 100 \\
3.5 & 25 & 0.355 & 74 \\
& 20 & 0.279 & 73 \\
& 15 & 0.202 & 72 \\
& 10 & 0.126 & 68 \\
2.5 & 5 & 0.049 & 58 \\
& 25 & 0.231 & 48 \\
& 20 & 0.177 & 46 \\
& 15 & 0.122 & 43 \\
1.5 & 10 & 0.067 & 37 \\
& 5 & 0.013 & 15 \\
& 25 & 0.108 & 22 \\
& 20 & 0.075 & 20 \\
& 15 & 0.042 & 15 \\
& 10 & 0.009 & 5 \\
& 5 & -0.023 & Negative \\
\hline
\end{tabular}

While AIC also did not place these models among the best-fit, further consideration of these models is warranted as additional data become available.

With the best-fit meta-analysis model (Eq. 1 in Table 3) $\mathrm{G}_{\mathrm{pf}}$ becomes temperature dependent as $\mathrm{RD}$ departs from maximum levels (Table 4). Unless additional data indicate this RD-T-G model has a fundamentally different form, where calculation of $G_{p f}$ is independent of temperature, our results along with other published studies suggest that larval size and temperature must be considered when using RD as a condition index. Thus, with the best-fit meta-analysis model, one could not assume that 2 larvae collected at different water temperatures, with equal but less than maximum RD estimates, have the same $\mathrm{G}_{\mathrm{pf}}$. Additional laboratory calibration studies, especially with warm water fishes, are needed to further resolve the shape of the RD-T-G relationship and yield a conclusive answer as to whether all SRD values can be directly compared without an adjustment for temperature.

\section{CONCLUSIONS}

After standardizing fluorometrically derived RD values (sRD), there appears to be a general equation that describes the relationship among sRD, T, and $\mathrm{G}$ in temperate marine fish larvae. Within the temperature range of tolerance of a given marine fish species, the general sRD-T-G relationship can be used to estimate $\mathrm{G}$ of larvae.

In well-fed larvae, no trend in sRD with temperature was seen. The mean value for 7 species at temperatures between 3 and $28^{\circ} \mathrm{C}$ was $3.20 \pm 0.49$ although this value is believed to be an underestimation of $\mathrm{RD}_{\max }$.

$\mathrm{RD}$ is an index of $\mathrm{G}_{\mathrm{pf}}$ and nutritional condition in marine fish larvae, but larval size and water temperature must be taken into account when interpreting the data.

Additional laboratory calibration experiments especially with warm water fishes, could improve the precision of the model.

Acknowledgements. The authors thank M. F. Canino, A. Folkvord, G. J. Holt, R. Kimura, C. Sato, K. Skajaa, and K.B. Suneetha for generously supplying their data and slope ratios. This study was partly supported by a DFG (German Research Foundation) research fellowship grant (CL 126/5-1) to C.C. This is contribution \# 610 of the US GLOBEC Program, funded jointly by NOAA and the National Science Foundation.

\section{LITERATURE CITED}

Belchier M, Clemmesen C, Cortes D, Doan T and others (2004) Recruitment studies: manual of precision and accuracy of tools. ICES Tech Mar Environ Sci No. 33, p 35

Berdalet E, Roldán C, Olivar MP, Lysnes K (2005) Quantifying RNA and DNA in planktonic organisms with SYBR Green II and nucleases, Part A. Optimisation of the assay. Sci Mar 69:1-16

Buckley LJ (1982) Effects of temperature on growth and biochemical composition of larval winter flounder Pseudopleuronectes americanus. Mar Ecol Prog Ser 8:181-186

Buckley LJ (1984) RNA-DNA ratio: an index of larval fish growth in the sea. Mar Biol 80:291-298

Buckley LJ, Durbin EG (2006) Annual and inter-annual trends in the zooplankton prey and growth rate of Atlantic cod (Gadus morhua) and haddock (Melanogrammus aeglefinus) larvae on Georges Bank. Deep-Sea Res II Top Stud Oceanogr 53:2758-2770

Buckley LJ, Turner SI, Halavik TA, Smigielski AS, Drew SM, Laurence GC (1984) Effects of temperature and food availability on growth, survival and RNA/DNA ratio of larval sand lance (Ammodytes americanus). Mar Ecol Prog Ser 15:91-97

Buckley L, Caldarone E, Ong TL (1999) RNA/DNA ratio and other nucleic acid-based indicators for growth and condition of marine fishes. Hydrobiologia 401:265-277

Buckley LJ, Caldarone EM, Lough RG, St. Onge-Burns JM (2006) Ontogenetic and seasonal trends in recent growth rates of Atlantic cod and haddock larvae on Georges Bank: effects of photoperiod and temperature. Mar Ecol Prog Ser 325:205-226

Caldarone EM (2005) Estimating growth in haddock larvae Melanogrammus aeglefinus from RNA:DNA ratios and water temperature. Mar Ecol Prog Ser 293:241-252

Caldarone EM, St. Onge-Burns JM, Buckley LJ (2003) Relationship of RNA/DNA ratio and temperature to growth in 
larvae of Atlantic cod Gadus morhua. Mar Ecol Prog Ser 262:229-240

Caldarone EM, Clemmesen CM, Berdalet E, Miller TJ and others (2006) Intercalibration of four spectrofluorometric protocols for measuring RNA/DNA ratios in larval and juvenile fish. Limnol Oceanogr Methods 4:153-163

> Campana SE (2001) Accuracy, precision and quality control in age determination, including a review of the use and abuse of age validation methods. J Fish Biol 59:197-242

Campana SE, Neilson JD (1985) Microstructure of fish otoliths. Can J Fish Aquat Sci 42:1014-1032

> Canino MF (1997) Nucleic acid contents and growth of firstfeeding walleye pollock larvae in response to prey densities typical of sub-Arctic ecosystems. J Fish Biol 51:41-52

Canino MF, Bailey KM, Incze LS (1991) Temporal and geographic differences in feeding and nutritional condition of walleye pollock larvae Theragra chalcogramma in Shelikof Strait, Gulf of Alaska. Mar Ecol Prog Ser 79:27-35

> Catalan IA, Olivar MP, Palomera I, Berdalet E (2006) Link between environmental anomalies, growth and condition of pilchard Sardina pilchardus larvae in the northwestern Mediterranean. Mar Ecol Prog Ser 307:219-231

> Chícharo MA, Esteves E, Santos AMP, dos Santos A, Peliz A, Ré P (2003) Are sardine larvae caught off northern Portugal in winter starving? An approach examining nutritional conditions. Mar Ecol Prog Ser 257:303-309

Clemmesen C (1993) Improvements in the fluorimetric determination of the RNA and DNA content of individual marine fish larvae. Mar Ecol Prog Ser 100:177-183

Clemmesen C (1994) The effect of food availability, age or size on the RNA/DNA ratio of individually measured herring larvae: laboratory calibration. Mar Biol 118(3):377-82

Clemmesen C, Sanchez R, Wongtschowski C (1997) A regional comparison of the nutritional condition of SW Atlantic anchovy larvae Engraulis anchoita based on RNA/DNA ratios. Arch Fish Mar Res 45:17-43

Farewell A, Neidhardt FC (1998) Effect of temperature on in vivo protein synthetic capacity in Escherichia coli. J Bacteriol 180:4704-4710

Fernandez AC (1997) Effect of temperature on larval fish growth: changes in RNA:DNA ratios of red drum (SCiaenops ocellatus). MA thesis, University of Texas at Austin

Folkvord A (2005) Comparison of size-at-age of larval Atlantic cod (Gadus morhua) from different populations based on size- and temperature-dependent growth models. Can J Fish Aquat Sci 62:1037-1052

Folkvord A, Ystanes L, Johannessen A, Moksness E (1996) RNA:DNA ratios and growth of herring (Clupea harengus) larvae reared in mesocosms. Mar Biol 126:591-602

Garcia A, Ramirez T, Cortes D, Guisande C, Quintanilla J (2006) Field comparison of sardine post-flexion larval growth and biochemical composition from 3 sites in the $\mathrm{W}$ Mediterranean (Ebro river coast, Bays of Almeria and Malaga). Sci Mar 70:79-91

- Grønkjær P, Clemmesen C, St. John M (1997) Nutritional condition and vertical distribution of Baltic cod larvae. J Fish Biol 51(Suppl A):352-369

Hauss HM (2008) Impacts of prey field characteristics on foraging and condition of larval herring Clupea harengus. MSc thesis, Christian-Albrechts-Universität, Kiel

> Herzka SZ, Holt GJ (2000) Changes in isotopic composition of red drum (Sciaenops ocellatus) larvae in response to dietary shifts: potential applications to settlement studies. Can J Fish Aquat Sci 57:137-147

Houde ED, Zastrow CE (1993) Ecosystem- and taxon-specific dynamic and energetic properties of larval fish assemblages. Bull Mar Sci 53:290-335
Houlihan DF, Hall SJ, Gray C, Noble BS (1988) Growth rates and protein turnover in Atlantic cod Gadus morhua. Can J Fish Aquat Sci 45:951-964

Jones CM (2002) Age and growth. In: Fuiman LA, Werner RG (eds) Fishery science: the unique contributions of early life stages. Blackwell Science, Malden, MA, p 33-63

Kimura R, Watanabe Y, Zenitani H (2000) Nutritional condition of first-feeding larvae of Japanese sardine in the coastal and oceanic waters along the Kuroshio Current. ICES J Mar Sci 57:240-248

Kondo K, Hori Y, Hiramoto K (1976) Life pattern of the Japanese sardine Sardinops melanosticta (Temminck et Schlegel) and its practical procedure of marine resources researches of the stock, 2nd edn. Japan Fish Resource Conserv Assoc, Tokyo (in Japanese)

> Lee O, Danilowicz BS, Dickey-Collas M (2006) Temporal and spatial variability in growth and condition of dab (Limanda limanda) and sprat (Sprattus sprattus) larvae in the Irish sea. Fish Oceanogr 15:490-507

> Malzahn AM, Clemmesen C, Wiltshire KH, Laakmann S, Boersma M (2007) Comparative nutritional condition of larval dab Limanda limanda and lesser sandeel Ammodytes marinus in a highly variable environment. Mar Ecol Prog Ser 334:205-212

Millward DJ, Garlick PJ, James WPT, Nnanyelugo DO, Ryatt JS (1973) Relationship between protein synthesis and RNA concentration in skeletal muscle. Nature 241:204-205

Mindell DP, Honeycutt RL (1990) Ribosomal RNA in vertebrates: evolution and phylogenetic applications. Annu Rev Ecol Syst 21:541-566

Morse WW (1989) Catchability, growth and mortality of larval fishes. Fish Bull 87:417-446

> Nielsen R, Munk P (2004) Growth pattern and growth dependent mortality of larval and pelagic juvenile North Sea cod Gadus morhua. Mar Ecol Prog Ser 278:261-270

> Otterlei E, Nyhammer G, Folkvord A, Stefansson SO (1999) Temperature- and size-dependent growth of larval and early juvenile Atlantic cod (Gadus morhua): a comparative study of Norwegian coastal cod and northeast Arctic cod. Can J Fish Aquat Sci 56:2099-2111

> Pepin P (1991) Effect of temperature and size on development, mortality, and survival rates of the pelagic early life history stages of marine fish. Can J Fish Aquat Sci 48: 503-518

Preedy VR, Paska L, Sudgen PH, Schofield PS, Sudgen MC (1988) The effects of surgical stress and short-term fasting on protein synthesis in vivo in diverse tissues of the mature rat. J Biochem 250:179-188

> Richard P, Bergeron J, Boulhic M, Galois R, Person-Le Ruyet J (1991) Effect of starvation on RNA, DNA and protein content of laboratory-reared larvae and juveniles of Solea solea. Mar Ecol Prog Ser 72:69-77

Rooker JR, Holt GJ, Holt SA (1997) Condition of larval and juvenile red drum (Sciaenops ocellatus) from estuarine nursery habitats. Mar Biol 127:387-394

Rossi-Wongtschowski CLDB, Clemmesen C, Ueberschaer B, Dias JF (2003) Larval condition and growth of Sardinella brasiliensis (Steindachner 1879): preliminary results from laboratory studies. Sci Mar 67:13-23

Saiz E, Calbet A, Fara A, Berdalet E (1998) RNA content of copepods as a tool for determining adult growth rates in the field. Limnol Oceanogr 43:465-470

Sato C, Kimura R, Nakata K, Umeda S, Suzuki M (1995) RNA/DNA ratio of first-feeding larvae of Japanese sardine. Fish Sci 61:538-539

Skajaa K, Fernö A, Folkvord A (2003) Swimming, feeding and predator avoidance in cod larvae (Gadus morhua L.): 
trade-offs between hunger and predation risk. In: Browman HI, Skiftesvik AB (eds) The big fish bang. Proc 26th Annu Larval Fish Conf, Institute of Marine Research, Bergen, Norway, p 105-121

St. John MA, Clemmesen C, Lund T, Köster T (2001) Diatom production in the marine environment: implications for larval fish growth and condition. ICES J Mar Sci 58:1106-1113

Suda M, Kishida T (2003) A spatial model of population dynamics of the early life stages of Japanese sardine Sardinops melanostictus off the Pacific coast of Japan. Fish Oceanogr 12:85-99

Suneetha KB, Folkvord A, Johannessen A (1999) Responsive-

Editorial responsibility: Kenneth Sherman,

Narragansett, Rhode Island, USA ness of selected condition measures of herring Clupea harengus larvae to starvation in relation to ontogeny and temperature. Environ Biol Fishes 54:191-204

> Wagenmakers EJ, Farrell S (2004) AIC model selection using Akaike weights. Psychon Bull Rev 11:192-196

Wagner MW, Campbell RG, Boudreau CA, Durbin EG (2001) Nucleic acids and growth of Calanus finmarchicus in the laboratory under different food and temperature conditions. Mar Ecol Prog Ser 221:185-197

Westerman M, Holt GJ (1994) RNA:DNA ratio during the critical period and early larval growth of the red drum Sciaenops ocellatus. Mar Biol 121:1-9

Submitted: August 3, 2007; Accepted: July 15, 2008

Proofs received from author(s): November 7, 2008 